\title{
Pengaruh Perilaku Pengambilan Resiko Dan Kelompok Referensi Terhadap Niat Berwirausaha Mahasiswa Pendidikan Ekonomi STKIP Nurul Huda Kabupaten Oku Timur
}

\author{
Siti Afifah \\ ${ }^{1}$ Fakultas Pendidikan Ekonomi, Universitas Jambi \\ *E-mail: sitiafifah37@yahoo.com
}

\begin{abstract}
Abstrak: Penelitian ini bertujuan untuk menganalisis pengaruh perilaku pengambilan resiko dan kelompok referensi terhadap niat berwirausaha. populasi penelitian ini adalah Mahasiswa Pendidikan Ekonomi Semester I, III dan V di STKIP dengan total 273 Mahasiswa. Pengambilan sampel mengunakan teknik sensus. Teknik pengumpulan data menggunakan kuesioner. Penelitian ini merupakan penelitian kuantitatif dengan analisis regresi linear berganda. Hasil menunjukkan bahwa ada pengaruh yang signifikan perilaku pengambilan resiko terhadap niat berwirausaha. ada pengaruh yang signifikan kelompok referensi terhadap niat berwirausaha. Secara simultan terdapat pengaruh perilaku pengambilan resiko dan kelompok referensi pada niat berwirausaha.
\end{abstract}

Kata Kunci: Perilaku Pengambilan Resiko, Kelompok Referensi, Niat Berwirausaha.

UTILITY: Jurnal IImiah Pendidikan dan Ekonomi

Permalink: https://journal.stkipnurulhuda.ac.id/index.php/utility/article/view/346

How to cite (APA): Afifah, S. (2018). Pengaruh Perilaku Pengambilan Resiko Dan Kelompok Referensi Terhadap Niat Berwirausaha Mahasiswa Pendidikan Ekonomi STKIP Nurul Huda Kabupaten Oku Timur. UTILITY: Jurnal IImiah Pendidikan Dan Ekonomi, 2(2), 111-128.

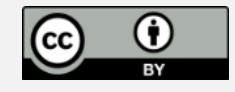

This is an open access article distributed under the terms of the Creative Commons Attribution 4.0 International License, which permits unrestricted use, distribution, and reproduction in any medium, provided the original work is properly cited.

\section{PENDAHULUAN}

Dengan perkembangan zaman dalam dunia pendidikan yang terus berubah dengan signifikan sehingga banyak merubah pola pikir pendidik, dari pola pikir yang awam dan kaku menjadi lebih modern dan Indonesia merupakan negara yang memiliki jumlah penduduk yang sangat banyak serta memiliki sumber kekayaan alam yang melimpah, ini membuat Indonesia pantas disebut sebagai negara yang kaya akan sumber dayanya, baik pada sumber daya alam maupun sumber daya manusia. Setiap tahun banyak mahasiswa yang lulus dari perguruan tinggi negeri maupun swasta yang dapat meningkatkan kualitas 
sumber daya manusia di Indonesia. Hal ini harusnya dapat memberikan keuntungan besar untuk perekonomian di Indonesia. Namun masih banyak pengangguran di Indonesia karena dunia usaha tidak mampu menampung seluruh calon tenaga kerja yang ada. Masalah pengangguran merupakan masalah yang menjadi tantangan besar bagi pemerintahan dan masyarakat Indonesia. Perkembangan ekonomi suatu negara dapat dilihat dari laju pertubuhan pelaku wirausaha. Pengembangan kewirausahaan pada beberapa tahun terakhir telah menjadi isu hangat pada lembaga-lembaga pendidikan di tingkat daerah, nasional bahkan internasional. Kecenderungan ini muncul karena adanya keyakinan bahwa kewirausahaan dapat menjadi kunci utama untuk sejumlah hasil sosial yang diinginkan, termasuk pertumbuhan ekonomi, pengangguran yang lebih rendah, dan modernisasi teknologi (Baumol, 2007). Menurut Van Praag dan Versloot (2007), kewirausahaan dapat menjadi perangsang dalam pertumbuhan ekonomi, inovasi, pekerjaan dan kreasi usaha.

Pengembangan kewirausahaan pada beberapa tahun terakhir telah menjadi isu hangat pada lembaga-lembaga pendidikan di tingkat daerah, nasional bahkan internasional. Kecenderungan ini muncul karena adanya keyakinan bahwa kewirausahaan dapat menjadi kunci utama untuk sejumlah hasil sosial yang diinginkan, termasuk pertumbuhan ekonomi, pengangguran yang lebih rendah, dan modernisasi teknologi (Baumol, 2007). Menurut Van Praag dan Versloot (2007), kewirausahaan dapat menjadi perangsang dalam pertumbuhan ekonomi, inovasi, pekerjaan dan kreasi usaha. Penelitian empiris juga mendukung hubungan positif antara aktivitas kewirausahaan terhadap pertumbuhan ekonomi.

Menurut Badan Pusat Statistik (Http://Ekonomi.Kompas.Com) mengungkapkan, pada tahun 2017 telah terjadi kenaikan jumlah pengangguran di Indonesia sebesar 10.000 orang menjadi 7,04 juta orang pada Agustus 2017 dari Agustus 2016 sebesar 7,03 juta orang. Meski mengalami peningkatan jumlah pengangguran jika dilihat dari Tingkat Pengangguran Terbuka (TPT) pada Agustus 2017 turun 0,11 poin dari 5,61 di Agustus 2016 menjadi 5,50 dipriode yang sama tahun 2017. Jumlah pengangguran setiap tahun semakin bertambah. Jumlah penduduk yang banyak, pertumbuhan penduduk yang semakin membludak serta tidak diimbangi dengan jumlah lapangan pekerjaan yang seimbang tentu akan berdampak buruk pada kesejahteraan hidup. 
Pengaruh Perilaku Pengambilan Resiko dan Kelompok Referensi Terhadap Niat Berwirausaha Mahasiswa Pendidikan Ekonomi STKIP Nurul Huda Kabupaten OKU Timur

Langkah awal yang di butuhkan dalam berwirausaha adalah niat. Menurut Rasli (2013), niat berwirausahaan adalah suatu pikiran yang mendorong individu untuk menciptakan usaha. Niat adalah keinginan tertentu seseorang untuk melakukan sesuatu atau beberapa tindakan, sebagai hasil dari pikiran sadar yang mengarahkan tingkah laku seseorang (Parker, 2004). Ramayah dan Harun (2005) mengatakan, niat berwirausaha didefinisikan sebagai kecenderungan individu untuk melakukan tindakan wirausaha dengan menciptakan produk baru melalui peluang bisnis dan pengambilan risiko. Kegiatan kewirausahaan sangat ditentukan oleh niat individu itu sendiri. Seseorang tidak akan menjadi pengusaha secara tiba-tiba tanpa pemicu tertentu. Upaya pemberdayaan masyarakat yang dilakukan oleh Kementrian Riset, Teknologi dan Pendidikan Tinggi adalah melalui pembenahan kurikulum pendidikan, mulai dari tingkat menengah sampai perguruan tinggi. Penambahan mata pelajaran/mata kuliah kewirausahaan kepada peserta didik bertujuan untuk menanamkan jiwa kewirausahaan pada generasi muda.

Mengembangkan sebuah usaha dalam bidang yang besar tentu dibutuhkan pemikiran yang besar pula dalam strategi pengembanganya. Dalam hal ini tidak dapat dipungkiri pelaku kewirausahaan bukan hanya orang yang membangun usaha tanpa memikirkan resiko. Menurut Meredith (2000) para wirausaha menyukai resiko yang raelistis karna ingin berhasil, para wirausha mendapat kepuasan besar dalam melaksanakan tugas yang sukar tetapi realistis dengan menerapkan keterampilan mereka. Sehingga resiko kecil ataupun resiko besar akan diminimalisir karena ingin berhasil. Banyak orang yang ingin mengelak dari resiko, karena selalu ingin aman dan hidup tentram, maka memang kebanyakan orang takut menanggung resiko. Namun semua tahap kehidupan kita mengandung resiko. Orang berusaha melindungi diri dari resiko, demikian pula badan usaha pun harus berusaha melindungi usahanya dari resiko. Jadi ketika kita berniat berwirausaha berarti kita harus siap dalam menanggung resiko (Herman, 2005).

Hasil penelitian yang dilakukan oleh Vemmy (2012) menyatakan variabel keberanian mengambil risiko memiliki pengaruh yang positif dan signifikan terhadap niat berwirausaha. Widhari (2012) menyatakan bahwa toleransi akan risiko memiliki pengaruh positif dan signifikan terhadap niat berwirausaha mahasiswa. Kecenderungan untuk berani mengambil risiko dan kemandirian keluarga menunjukkan niat besar mereka untuk memulai berwirausaha (Ertuna dan Gurel, 2010). Demikian pula hasil penelitian yang dilakukan oleh Barbosa 
(2007) bahwa keberanian seseorang dalam mengambil risiko yang tinggi maka niat berwirausaha yang dimiliki juga lebih tinggi. Wibowo (2017) menyatakan pengambilan resiko berpengaruh signifikan terhadap niat berwirausaha mahasiswa. Menjadi seorang wirausaha tentunya harus siap berani mengambil resiko semakin tinggi harapan berwirausaha maka akan semakin tinggi pula niat seseorang untuk berwirausaha. Namun hasil yang berbeda dinyatakan oleh Silvia (2013) dimana terdapat hubungan tidak langsung antara risk-taking prospensity, market awareness dan niat berwirausaha. Berdasarkan uraian tersebut, hipotesis yang akan dijawab pada penelitian ini adalah:

$\mathrm{H}_{1}$ : Perilaku Pengambilan Resiko berpengaruh signifikan terhadap niat berwirausaha

Menurut teori perkembangan karir oleh Ginzberg (dalam Rahma, 2010), perkembangan seorang individu dalam menentukan pilihan pekerjaan dan karirnya melalui proses yang berlangsung dalam waktu yang relatif panjang dan melalui fase-fase perkembangan mengikuti perkembangan individu itu sendiri. Fase fantasi mencakup usia kira-kira sepuluh atau dua belas tahun, fase tentatif usia 11 sampai 18 tahun dan fase realistis yaitu masa anak mulai bekerja. Sesuai dengan teori perkembangan dan pemilihan karir yang dikemukakan oleh Ginzberg tersebut, maka dalam perkembangannya pilihan karir anak dipengaruhi oleh keluarga dan sekolahnya. Untuk itu merupakan tanggung jawab sekolah dan keluarga untuk meningkatkan intensi berwirausaha anak. Capara et.al (2003) dalam penelitiannya mengemukakan bahwa orang tua yang memiliki keyakinan yang tinggi dalam mengawasi, mendukung, melindungi, mengarahkan, membesarkan hti, dan menyediakan waktu bagi anak-anaknya, memberikan hukuman apabila diperlukan sehingga tidak terjadi konflik, dapat membantu perkembangan aspirasi dan kemampuan anak, dengan demikian dapat meningkatkan hubungan sosial anak, kestabilan emosi, peningkatan prestasi dan pemilihan kerja atau karir yang hendak ditekuninya. Pemilihan karir atau pekerjaan yang ditekuni oleh seseorang dalam perkembangannya melalui proses yang berlangsung dalam waktu yang relatif panjang dan melalui fase-fase perkembangan individu dari masa anak-anak sampai dewasa. Hal ini berarti pemilihan karir seseorang tidak dapat dilepaskan dari pengaruh kelompok referensinya dalam hal ini lingkungan keluarga dan teman sebaya. Dijelaskan pula oleh Chen dan Lai (2010) bahwa kegagalan dan keberhasilan keluarga dalam usaha memenuhi kebutuhannya akan mempengaruhi minat dan 
Pengaruh Perilaku Pengambilan Resiko dan Kelompok Referensi Terhadap Niat Berwirausaha Mahasiswa Pendidikan Ekonomi STKIP Nurul Huda Kabupaten OKU Timur

pilihan anak untuk memenuhi kebutuhannya sendiri di masa yang akan datang. Lingkungan keluarga yaitu dimana seseorang mendapatkan pendidikan pertamanya, teman sebaya dimana seseorang mengembangkan pergaulannya, pendidikan di sekolah dimana seseorang mendapatkan pendidikan lebih lanjut. Dijelaskan pula oleh Patrikha (2015) menunjukkan bahwa kelompok referensi berpengaruh positif terhadap intensi berwirausaha siswa. Dengan demikian dukungan dan peran dari orang-orang terdekat, melihat gaya hidup, prilaku dan melihat peluang, dapat mendorong seseorang untuk berwirausaha akan menumbuhkan niat untuk berwirausaha. Berdasarkan uraian tersebut, hipotesis yang akan dijawab pada penelitian ini adalah:

$\mathrm{H}_{2}$ : Kelompok referensi berpengaruh terhadap niat berwirausaha.

\section{METODE}

Penelitian ini akan mengkaji pengaruh perilaku pengambilan resiko dan kelompok referensi terhadap niat berwirausaha. Metode pendekatan yang digunakan dalam penelitian ini adalah deskriptif dan jenis penelitiannya adalah penelitian kuantitatif. Penelitian kuantitatif ini yaitu data penelitian berupa angka-angka dan analisis menggunakan statistik (Sugiono, 2008:7).

Desain penelitian yang digunakan dalam penelitian ini adalah metode sensus dan dalam pengumpulan datanya penelitian menggunakan angket, maka sebaiknya subjek sejumlah itu diambil seluruhnya atau yang disebut dengan sensus. Dalam penelitian ini metode sensus dalam menyebarkaan angket. Teknik analisis menggunakan analisis regresi linear berganda dengan kriteria uji $\mathrm{F}$ dan uji t. Uji $\mathrm{F}$ digunakan untuk menguji signifikansi variabel prilaku pengambilan resiko dan kelompok referensi pada niat berwirausaha secara simultan. Sedangkan uji t digunakan untuk menguji signifikansi perilaku pengambilan resiko dan kelompok referensi terhadap niat berwirausaha secara parsial.

\section{HASIL DAN PEMBAHASAN}

Berdasarkan hasil penelitian yang telah dilaksanakan, hasil dari SPSS 23 digunakan untuk mengetahui hipotesis penelitian : 
$\mathrm{H}_{1}$ : Terdapat pengaruh positif perilaku pengambilan resiko terhadap niat berwirausaha.

$\mathrm{H}_{2}$ : Terdapat pengaruh positif kelompok referensi terhadap niat berwirausaha.

$\mathrm{H}_{3}$ : Terdapat pengaruh secara stimultan antara perilaku pengambilan resiko dan kelompok referensi terhadap niat berwirausaha.

Berikut hasil analisis data SPSS 23

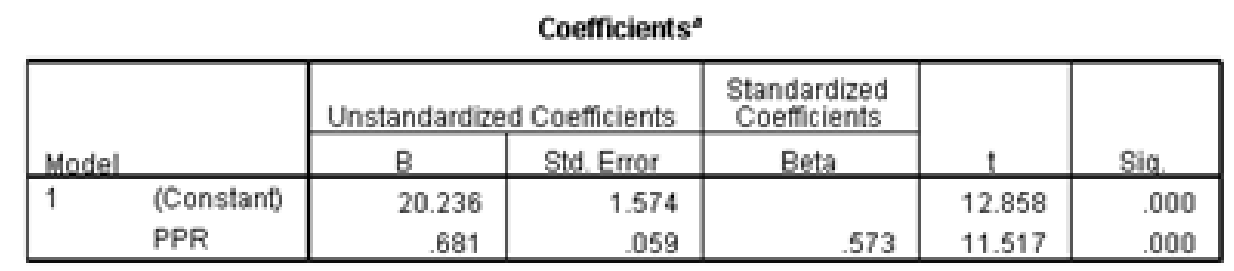

a. Dependent Variable: NB

Tabel 1. Perilaku Pengambilan Keputusan Terhadap Niat Berwirausaha

Dari tabel diatas terlihat bahwa nilai t hitung perilaku pengambilan resiko $=11.517$ sedangkan untuk nilai $\mathrm{t}$ tabel $=1.968889$. Dasar pengambilan keputusan Uji t yaitu Jika nilai sig $<0,05$ atau $t$ hitung $>\mathrm{t}$ tabel maka terdapat pengaruh. Jadi diketahui nilai sig untuk pengaruh perilaku pengambilan resiko terhadap niat berwirausa adalah sebesar $0,000<0,05$ dan nilai t hitung 11.517 $>$ 1.968889. sehingga dapat disimpulkan bahwa $\mathrm{H} 1$ diterima yang berarti terdapat pengaruh perilaku pengambilan resiko terhadap niat berwirausaha.

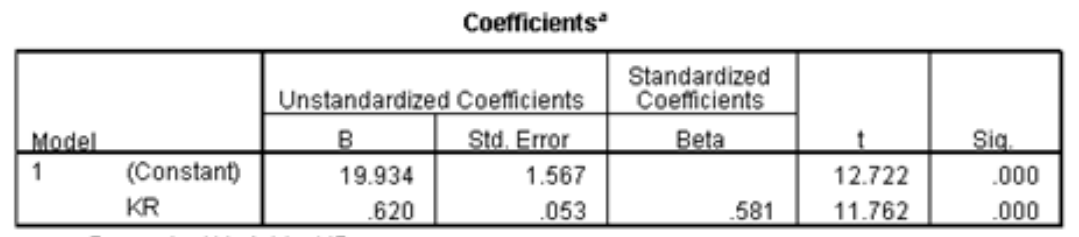

a. Dependent Variable: NB

Tabel 2. Kelompok Referensi Terhadap Niat Berwirausaha

Dari tabel diatas terlihat bahwa nilai t hitung kelompok referensi $=11.762$ sedangkan untuk nilai t tabel $=1.968889$. Dasar pengambilan keputusan Uji t yaitu Jika nilai sig $<0,05$ atau $t$ hitung $>\mathrm{t}$ tabel maka terdapat pengaruh. Jadi diketahui nilai sig untuk pengaruh kelompok referensi terhadap niat berwirausaha adalah sebesar $0,000<0,05$ dan nilai t hitung $11.762>1.968889$. 
Pengaruh Perilaku Pengambilan Resiko dan Kelompok Referensi Terhadap Niat Berwirausaha Mahasiswa Pendidikan Ekonomi STKIP Nurul Huda Kabupaten OKU Timur

sehingga dapat disimpulkan bahwa $\mathrm{H} 2$ diterima yang berarti terdapat pengaruh kelompok referensi terdapat niat berwirausaha.

\begin{tabular}{l} 
Model Summary \\
\begin{tabular}{|l|l|r|r|r|}
\hline Mode & $\mathrm{R}$ & $\mathrm{R}$ Square & $\begin{array}{c}\text { Adjusted R } \\
\text { Square }\end{array}$ & $\begin{array}{c}\text { Std. Error of } \\
\text { the Estimate }\end{array}$ \\
\hline 1 & $.617^{2}$ & .381 & .376 & 4.21391 \\
\hline
\end{tabular} \\
\hline
\end{tabular}

\section{Tabel 3. Nilai Koefisien Determinasi}

Berdasarkan output diatas diketahui nilai R Square sebesar 0.381. Hal ini mengandung arti bahwa pengaruh perilaku pengambilan resiko( $\left.\mathrm{X}_{1}\right)$, kelompok referensi $\left(\mathrm{X}_{2}\right)$ terhadap niat berwirausaha $(\mathrm{Y})$ secara stimultan sebesar 38,1\%, sedangkan sisanya $61,9 \%$ lagi dipengaruhi oleh variabel-variabel lain diluar penelitian ini. Untuk melihat bentuk persamaan regresi linier bergandanya maka dapat disusun berdasarkan tabel di bawah ini:

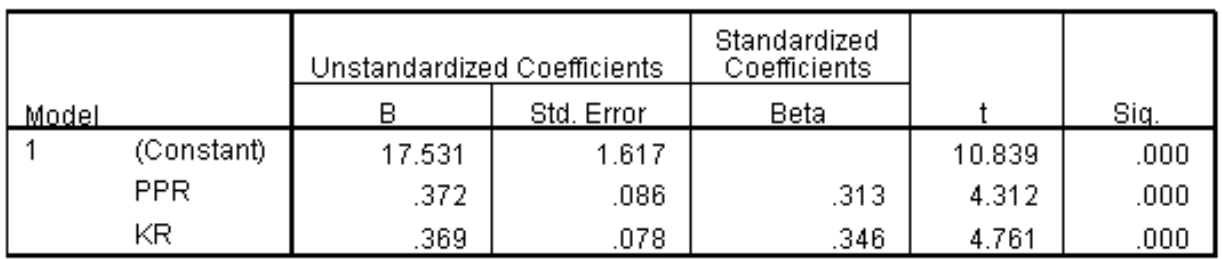

a. Dependent Variable: NB

Tabel 4. Nilai Koefisien Regresi Berganda - Perilaku Pengambilan Resiko dan Kelompok Referensi Terhadap Niat Berwirausaha

Dari tabel diatas dapat disusun persamaan regresinya sebagai berikut:

$\mathrm{Y}=17.531+0.313+0.346+\mathrm{e}$

Interprestasi dari regresi linier berganda di atas adalah nilai kostanta sebesar. Secara sistematis menyatakan bahwa nilai perilaku pengambilan resiko sebagai $\left(\mathrm{X}_{1}\right)$, nilai kelompok referensi sebagai $\left(\mathrm{X}_{2}\right)$ sama dengan nol atau 0 maka nilai niat berwirausaha (Y) sebesar 17.531. Dengan kata lain niat berwirausaha tanpa ada prilaku pengambilan resiko dan kelompok referensi adalah 17.531. Koefisien regresi prilaku pengambilan resiko $\left(\mathrm{X}_{1}\right)$ terhadap niat berwirausaha (Y) sebesar 0.313 artinya bahwa peningkatan satu variabel perilaku pengambilan keputusan dengan asumsi 2 variabel yang lain konstan maka akan menyebabkan penambahan niat berwirausaha sebesar 0.313. Koefisien regresi kelompok referensi $\left(\mathrm{X}_{2}\right)$, terhadap niat berwirausaha $(\mathrm{Y})$ 
sebesar 0.346 artinya bahwa peningkatan satu variabel kelompok referensi dengan asumsi 2 variabel yang lain konstan maka akan menyebabkan penambahan niat berwirausaha sebesar 0.346 .

Berdasarkan hasil penelitian yang dilakukan peneliti di kampus STKIP Nurul Huda di OKU Timur pada pendidikan Ekonomi didapatkan hasil bahwa terdapat pengaruh perilaku pengambilan resiko terhadap niat berwirausaha secara signifikan. Seperti dalam penelitian Wibowo dan Suasana, (2017) penelitiannya tentang "pengaruh efikasi diri, pengambilan risiko, dan inovasi terhadap niat berwirausaha mahasiswa feb universitas udayana" hasil penelitian menunjukan ketiga variabel bebas (efikasi diri, pengambilan resiko, dan inovasi) berpengaruh signifikan terhadap niat berwirausaha mahasiswa. Menjadi seorang wirausaha tentunya harus siap berani mengambil resiko, semakin berani seseorang mengambil resiko semakin tinggi harapan berwirausaha maka akan semakin tinggi pula niat seseorang untuk berwirausaha. Hasil penelitian yang dilakukan oleh Vemmy (2012) menyatakan variabel keberanian mengambil risiko memiliki pengaruh yang positif dan signifikan terhadap niat berwirausaha. Widhari (2012) menyatakan bahwa toleransi akan risiko memiliki pengaruh positif dan signifikan terhadap niat berwirausaha mahasiswa. Kecenderungan untuk berani mengambil risiko dan kemandirian keluarga menunjukkan niat besar mereka untuk memulai berwirausaha (Ertuna dan Gurel, 2010). Demikian pula hasil penelitian yang dilakukan oleh Barbosa (2007) bahwa keberanian seseorang dalam mengambil risiko yang tinggi maka niat berwirausaha yang dimiliki juga lebih tinggi. Namun hasil yang berbeda dinyatakan oleh Silvia (2013) dimana terdapat hubungan tidak langsung antara risk-taking prospensity, market awareness dan niat berwirausaha. Yurtkorua, Acarb dan Teraman (2014), Selain manfaatnya bagi banyak organisasi, kewirausahaan dianggap sebagai fenomena penting bagi banyak penelitian. Hasil dari studi ini, ia berpendapat bahwa faktor kepribadian kewirausahaan tidak cukup untuk memiliki hasil yang dapat diandalkan dan dapat digeneralisasikan, dengan demikian perhatian dikembalikan ke proses yang disengaja. Juga mengambil risiko kemauan diyakini menjadi faktor pembeda untuk fitur kewirausahaan. Sejalan dengan literatur, tujuan dari penelitian ini adalah untuk mengukur pengaruh kesediaan untuk mengambil risiko niat kewirausahaan dan membandingkan mahasiswa negeri dan swasta. 207 negara dan 214 mahasiswa swasta dianalisis dan hasilnya mengungkapkan beberapa perbedaan antara dua kelompok dan 
Pengaruh Perilaku Pengambilan Resiko dan Kelompok Referensi Terhadap Niat Berwirausaha Mahasiswa Pendidikan Ekonomi STKIP Nurul Huda Kabupaten OKU Timur

sebagian pengaruh kesediaan untuk mengambil risiko pada niat kewirausahaan. Dan dari hasil penelitian di dapatkan di STKIP Nurul Huda OKU Timur bahwa dari 273 mahasiswa yang menjadi responden dengan prilaku pengambilan resiko dengan kategori sangat tinggi sebanyak 130 responden dengan prosentase 48\%, dan kategori tinggi 143 responden dengan prosentase 52\%.

Berdasarkan hasil penelitian yang dilakukan peneliti di kampus STKIP Nurul Huda di OKU Timur pada pendidikan Ekonomi didapatkan hasil bahwa terdapat pengaruh kelompok referensi terhadap niat berwirausaha secara signifikan. Seperti dalam penelitan Patrikha, (2015). penelitiannya tentang "pengaruh kelompok referensi, motif ekonomi dan pendidikan kewirausahaan di sekolah terhadap intensi berwirausaha siswa smk di kota malang" hasil penelitian ini menunjukkan bahwa kelompok referensi dan pendidikan kewirausahaan di sekolah berpengaruh positif terhadap intensi berwirausaha siswa. Dengan demikian dukungan dan peran dari orang-orang terdekat, melihat gaya hidup, prilaku dan melihat peluang, dapat mendorong seseorang untuk berwirausaha akan menumbuhkan niat untuk berwirausaha. Bagheri dan Pihie (2010) menyatakan bahwa anak yang berasal dari keluarga wirausaha dan ikut terlibat di dalam menjalankan usaha keluarga meningkatkan keyakinan dan kepercayaan diri pada anak untuk menjadi wirausaha. Apabila siswa mendapatkan kesempatan untuk mengelola usaha dalam keluarga, maka tanpa disadari bahwa siswa telah mengambil pengetahuan dalam mengelola usaha. Bagi anak yang berasal dari keluarga wirausaha memiliki kesempatan untuk menjalankan usaha sejak usia dini dan ikut terlibat dalam usaha keluarga, siswa akan merasa yakin dan mampu mengatasi masalah dan yakin untuk menjalankan usaha sendiri di masa yang akan datang. Keluarga juga dapat memberikan pengaruh lewat kekuatan informasi dan kekuatan referensi yang dimiliki kepada siswa dalam mempertimbangkan pemilihan suatu karir yang akan ditekuninya. Hasil penelitian ini mendukung hasil penelitian yang dikemukakan oleh Chen dan Lai (2010) dalam penelitiannya di Taiwan menyatakan bahwa keinginan anak untuk berwirausaha di masa yang akan datang dapat dikuatkan dengan pengalaman yang dimiliki keluarganya dalam berwirausaha. Kesuksesan dan kegagalan yang dialami oleh keluarganya dalam menjalankan usaha dapat menguatkan keinginan anak untuk mengikuti jejak orang tuanya dan menjadi seorang wirausaha. Latar belakang ekonomi keluarga merupakan penghambat pemilihan karir yang diminati oleh siswa. Minat siswa akan suatu pekerjaan berawal dari ketertarikan dan merupakan sumber yang 
mendorong siswa untuk melakukan suatu kegiatan. Siswa yang berasal dari keluarga kurang mampu cenderung untuk langsung masuk dunia kerja atau menjadi pencari kerja. Melakukan pekerjaan apapun yang diperolehnya setelah lulus sekolah untuk membantu ekonomi keluarga walaupun pekerjaan tersebut tidak sesuai dengan minat dan potensi yang dimilikinya. Walaupun latar belakang pekerjaan orang tua bukan wirausaha, namun tidak menutup kemungkinan bagi anak untuk memperoleh pendidikan kewirausahaan dalam keluarga. Pendidikan kewirausahaan yang diperoleh oleh anak dalam keluarga selain keteladan orang tua dalam berwirausaha juga dapat melalui komunikasi orang tua mengenai kewirausahaan. Semakin sering komunikasi dalam keluarga yang diberikan oleh orang tua tentang kewirausahaan, maka semakin bertambah pula pengetahuan yang diterima oleh anak. Meskipun berasal dari keluarga yang berwirausaha, namun jika transfer ilmu atau informasi akan kewirausahaan antara orang tua dan anak kurang, maka minat anak untuk berwirausaha juga rendah. Transfer ilmu kewirausahaan antara orang tua dan anak dapat berupa pengalaman orang tua dalam memenuhi kebutuhan sehari-hari, intensitas komunikasi dengan anak, semakin sering komunikasi akan kewirausahaan dilakukan maka semakin bertambah pula pengetahuan anak akan kewirausahaan. Pendidikan kewirausahaan dalam keluarga tidak seperti pendidikan disekolah yang mempunyai tujuan yang tercantum dalam kurikulum. Pendidikan kewirausahaan dalam keluarga tidak memiliki batas waktu dan tolak ukur penilain, dan dapat berlangsung kapan saja. Pendidikan kewirausahaan dalam keluarga dapat berupa komunikasi untuk menambah pengetahuan anak akan kewirausahaan, bentuk keteladanan orang tua dalam pemenuhan kebutuhan sehari-hari. Cara orang tua dalam meraih suatu keberhasilan dalam pemenuhan kebutuhan keluarga merupakan modal yang baik untuk melatih minat. Kelompok referensi teman sebaya berdasarkan hasil penelitian dapat diketahui memiliki pengaruh terhadap intensi berwirausaha siswa, hasil penelitian ini mendukung hasil temuan Humbert dan Drew (2010) bahwa salah satu faktor yang memepengaruhi keinginan seseorang untuk berwirausaha adalah faktor teman. Teman sebaya adalah tempat dimana siswa dapat bersosialisasi, aturan dan norma yang berlaku dalam kelompok dapat mempengaruhi siswa untuk mengambil keputusan. Pemilihan karir wirausaha juga dipengaruhi oleh harapan - harapan mahasiswa akan karir yang baik, pengembangan karir serta harapan akan pendapatan yang lebih baik. Kelompok referensi memiliki pengaruh terhadap pertimbangan, sudut pandang serta 
Pengaruh Perilaku Pengambilan Resiko dan Kelompok Referensi Terhadap Niat Berwirausaha Mahasiswa Pendidikan Ekonomi STKIP Nurul Huda Kabupaten OKU Timur

keinginan siswa untuk memilih suatu karir yang akan ditekuninya. Fatoki (2010) Hasil penelitiannya menunjukkan bahwa meskipun siswa laki-laki memiliki tingkat niat kewirausahaan yang lebih tinggi dibandingkan dengan siswa perempuan, perbedaannya tidak signifikan secara statistik. Hasilnya juga menunjukkan bahwa siswa yang orangtuanya Terlibat dalam bisnis memiliki tingkat niat kewirausahaan yang lebih tinggi dibandingkan dengan siswa yang orang tuanya tidak terlibat dalam bisnis. Namun, perbedaannya tidak signifikan secara statistik. Dan dari hasil penelitian di dapatkan di STKIP Nurul Huda OKU Timur bahwa dari 273 mahasiswa yang menjadi responden dengan kelompok referensi dengan kategori sangat tinggi sebanyak 127 responden dengan prosentase $47 \%$, dan kategori tinggi 146 responden dengan prosentase $53 \%$.

\section{SIMPULAN}

Berdasarkan hasil analisis penelitian dan hasil pembahasan yang telah dilakukan, maka kesimpulan yang diperoleh yaitu Perilaku pengambilan resiko di STKIP Nurul Huda OKU Timur dalam kategori sangat tinggi. Perilaku pengambilan resiko berpengaruh positif dan signifikan terhadap niat berwirausaha mahasiswa pendidikan ekonomi di STKIP Nurul Huda OKU Timur. Artinya semakin tinggi perilaku pengambilan resiko maka niat berwira usaha semakin tinggi pula, Kecenderungan untuk berani mengambil risiko menunjukkan niat besar mereka untuk memulai berwirausaha.

Kelompok referensi di STKIP Nurul Huda OKU Timur dalam kategori sangat tinggi. Kelompok referensi berpengaruh positif dan signifikan terhadap niat berwirausaha mahasiswa pendidikan ekonomi di STKIP Nurul Huda OKU Timur. Artinya bahwa dukungan dan peran dari orang-orang terdekat, melihat gaya hidup, prilaku dan melihat peluang, dapat mendorong seseorang untuk berwirausaha akan menumbuhkan niat untuk berwirausaha.

\section{SARAN}

Berdasarkan hasil penelitian dan kesimpulan tersebut maka dapat diajukan saran yaitu Pelaksanaan pendidikan kewirausahaan perlu mendapat perhatian serius dari pemerintah dan lembaga pendidikan mengenai bagaimana metode pengajaran, kurikulum, kompetensi dosen, dan lamanya waktu belajar sehingga 
dapat menstimulasi niat berwirausaha pada mahasiswa. Beberapa saran yang dapat diberikan kepada peneliti selanjutnya yaitu perlu dipertimbangkan untuk meneliti faktor-faktor lain pengambilan risiko dan kelompok referensi untuk mengetahui niat berwirausaha mahasiswa, karena masih banyak faktor-faktor lain yang dapat mempengaruhi niat berwirausaha mahasiswa. Menambah jumlah responden dan memperluas sampel penelitian bukan hanya pada mahasiswa program pendidikan enkonomi saja, namun dapat pula dilakukan pada program studi lainnya. Memperluas cakupan wilayah penelitian tidak hanya di wilayah lingkungan pendidikan Ekonomi.

\section{REFERENSI}

Alma,H. Buchari. 2013” Kewirausahaan”. Bandung : Alfabeta.

Akbar Cahyo Wibowo, Dkk (2017). "Pengaruh Efikasi Diri, Pengambilan Risiko, Dan Inovasi Terhadap Niat Berwirausaha Mahasiswa Feb Universitas Udayana”. E-Jurnal Manajemen Unud, Vol 6, No. 105693 5719.

Arikunto, Suharsimi. 2010. Prosedur Penelitian Suatu Pendekatan Praktik. Jakarta: Rineka Cipta.

As’ad M. 2005.”Psikologi Industri”. Yogyakarta : Liberti.

Ati, Sisilia Elnora Ilpetra Sriyanti Tae. (2000). Hubungan Antara Pengaruh Kelompok Referensi Dengan Loyalitas Merek. Skripsi [online]. Universitas Katolik Soegijapranata Semarang. http://eprints.unika.ac.id/ diakses pada 12 April 2015.

Atkinson, J. W. 1985. Motives in Fantacy, Action and Society. New York : D. Van Nostrand Company inc.

Baharudin dan Wahyuni. 2010. Teori Belajar dan Pembelajaran. Yogyakrta : Ar-Ruzz media.

Baron, R. A. \& Byrne. D. 1991. Social Psychology : Understanding Human Interaction. New York: Allyn \& Beacon.

Barbosa, S.D.M.W.Gerhard., dan J.R. Kickul. 2007. The Role of Cognitive Style and Risk Preference on Entrepreneurial Intentions. Journal of Leadership and Organizational Studies, 3 (4): 87-104. 
Pengaruh Perilaku Pengambilan Resiko dan Kelompok Referensi Terhadap Niat Berwirausaha Mahasiswa Pendidikan Ekonomi STKIP Nurul Huda Kabupaten OKU Timur

Bass, B. M. \& Stogdill. 1990. Handbook Of Leadership: Theory Research \& Manajemen Applicaation, $3^{\text {th }}$ Edition. New York : The Press.

Baumol, W. J., Litan, R. E., dan Schramm, C. J. 2007. Sustaining entrepreneurial capital ism. Capitalism and Society, 2(2) Article 1. Available at: http://www.bepress.com/cas/vol2/iss2/art1.

Bhandari, 2006. "Intention For Entrepreneurship Among Student In India. Journal Entrepreneurship 15(2), pp:169-171".

Bygrave, W.D. 2003. The Portable MBA Entrepreneurrship. Jakarta : Binarupa Aksara.

Cahyono, S.B. 2008. "Gaya Hidup dan Penyakit Modern”. Yogyakarta : Kanisius.

Chen, Y. \& Lai, M. 2010. Factors Influencing The Entrepreneurial Attitude Of Taiwanese Tertiary-Level Business Students. Social Behavior And Personality Vol. 38 No. 1pp. 1-12.

Darojat, Dkk(2013). Pendidikan Kewirausahaan, Banten.

Daryanto.(2012). Menggeluti Dunia Wirausaha. Yogyakarta : Gava Media.

Desmita.(2005). Psikologi perkembangan. Bandung: Remaja Rosdakarya.

Dwijayati, Finisica. P. (2015). Pengaruh Kelompok Referensi, Motif Ekonomi Dan Pendidikan Kewirausahaan Di Sekolah Terhadap Intensi Berwirausaha Siswa Smk Di Kota Malang. Universitas Negeri Surabaya: Jurnal Ekonomi Pendidikan Dan Kewirausahaan. Vol 3 No 1. Hal 1-15.

Ertuna, Z.I., dan E. Gurel. 2011. The moderating Role of Higher Education on Entrepreneurship. Education + Training, 53 (5): 387-402.

Fatoki, O. 2010. Graduate entrepreneurial intention in South Africa: Motivations and obstacles. International Journal of Business and Management Vol. 5 No. 9 pp. 87-98. 
Ferdinand, Augusty. 2011. Metode Penelitian Manajemen. Semarang: Badan Penerbit Universitas Diponegoro.

Gujarati, Damodar N. Dan Dawn C. Porter. 2010. Dasar-Dasar Ekonometrika. Jakarta: Salemba Empat.

Hastjarjo, T. D.1991. Pendekatan Psikofisika dan Kognetif Terhadap Tingkah Laku Memilih. Makalah. Yogyakartaa : Fakultas Psikologi UGM.

Kana, Tarsisius. Pengaruh Kelompok Referensi, Keluarga Dan Komunikasi Pemasaran Terhadap Keputusan Mahasiswa Dalam Memilih Perguruan Tinggi Universitas Musamus Merauke. Universitas Musamus Merauke. Hal: 1-10.

Kotler, Philip, Dan Keller, Kevin, Lane, (2007)Manajemen Pemasaran, Jilid 1, Edisi Ketiga Belas, Erlangga, Jakarta.

Kotler, P., Dan Keller, K.L. (2006).Marketing Management.12e. New Jersey: Pearson Prentice Hall.

Kurjono, 2010. Proses Belajar Mengajar Dengan Aspek-aspeknya Panduan bagi para Pendidik, Mahasiswa dan Para Praktisi Pendidikan. Bandung : Program Studi Pendidikan Akuntansi.

Larasati, A.B. 1993. "Risk Taking Behavior, Makalah. Seminar sehari"Manajemen Resiko" dari Petualangan Sampai Dunia Kerja. Yogyakarta : Fakultas Psikologi Universitas Gajah Mada.

Levenson, M.R.1990. Risk Taking and Personality. Journal of Personality and Social Psychology, 58, 6, 1073-1080.

Liana, Yuyuk. 2014. Intensi Wirausaha Mahasiswa Untuk Menciptakan Kemandirian Mahasiswa Dalam Berwirausaha. Dosen STIE Malangkucecwara Malang. Jabm, Volume 21, Nomor 1. Hal: 45-56.

Mcclelland, J.S. (1987). Human Motivation. New York: Cammbridge Universty Pers.

Meredith, Geoffrey G.(2000). Kewirausahaan Teori Dan Praktek. Jakarta: Pustaka Binaman Pressindo. 
Pengaruh Perilaku Pengambilan Resiko dan Kelompok Referensi Terhadap Niat Berwirausaha Mahasiswa Pendidikan Ekonomi STKIP Nurul Huda Kabupaten OKU Timur

Mudjiarto dan Aliaras Wahid, 2005. "Membangun Karakter dan Kepribadian Kewirausahaan”, Edisi Pertama, Cetakan Pertama, Yogyakarta dan Jakarta : Graha Ilmu dan UIEU Universty Press.

Nasution, A.H.(2007). Entrepreneurship : Membangun Spirit Teknopreneurship. Yogyakarta: Penerbit Andi.

Nirbito, 2000."Manajemen Perusahaan Kecil dan Kewirausahaan : Konsep, Prinsip dan Aplikasi”. Jakarta : Proyek Pengembangan Guru Sekolah Menengah. Ditjen Dikti, Depdiknas.

Nugroho, J Setiadi.(2003). Perilaku Konsumen. Kencana, Jakarta.

Oktavia, Nining.(2016). Pengaruh Pelatihan Prilaku Pengambilan Resiko Terhadap Peningkatan Karakter Kewirausahaan. Skripsi. Universita Islam Negeri Sunan Kalijaga : Yogyakarta.

Purwanto, Heri. (2017). Pengaruh Intensi Berwirausaha Dan Orientasi Kewirausahaan Terhadap Kinerja Usaha ( Studi Kasus Di Sentra Umkm Pengrajin Teralis Di Desa Jl amprang Kecamatan Wonosobo ). Fakultas Ekonomi Universitas Sains Al-Qur'an. Jurnal Ppkm I 90-104.

Rahma, Ulifa. 2010. Bimbingan Karier Siswa. Malang: Uin-Maliki Press.

Rasli, Amran., Khan, S.U.R., Malekifar, S., dan Samrena Jabeen. 2013. Factors Affecting Entrepreneurial Intention Among Graduate Students of Universiti Teknologi Malaysia. International Journal of Business and Social Science, 4 (2): 182-188.

Robert, Hisrich D, Michael P Peters dan Dean A Sheperd. 2008. "Kewirausahaan Terjemah Criswan Sungkono Diana Angelica". Jakarta : Salemba Empat.

Salusu, 2004. Pengambilan Keputusan Stratejik Untuk Organisasi Publik Dan Organisasi Non Profit. Jakarta: Pt Gramedia.

Sarwoko, E. 2011. Kajian Empiris Entrepreneur Intention Mahasiswa. Jurnal Ekonomi Bisnis, 16 (2): 126-135.

Sausan Afra Nafisah,(2017). Hubungan Antara Orientasi Masa Depan Dengan Kesiapan Kerja Siswa Smk. Universitas Muhammadiyah Surakarta. Jurusan Psikologi. 
Schiffman, L., \& Kanuk, L.L. (2008).Perilaku Konsumen. Jakarta. Pt. Indeks.

Schiffman, Leon, G And Leslie, Lazar, Kanuk. (2004). Consumen Behavior, Edition 8. Pearson Educationinternational, United State Of America.

Silvia. 2013. Pengaruh Entrepreneurial Traits Dan Entrepreneurial Skills Terhadap Intensi Kewirausahaan: Studi Empiris Dapak Pendidikan Kewirausahaan Pada Mahasiswa Universitas Kristen Petra Surabaya. Agora, 1(1): 1-7.

Slovic, P. Fischhoff, B. Dan Lichtrnstein, S. 1987. Taking Care : Understanding and Encouraging Self-Protective Behavior. New York : Cambridge Univ. Press.

Soemanto, Wasty. 2002. “Pendidikan Wiraswasta”. Jakarta : Bumi Aksara.

Stoner, J.A.F., \& Freeman, R.E. 1989. Management $4^{\text {th }}$ Edition.

Sudarsono,Eddy Soegoto, 2009. “Entrepreneurship”, Edisi Pertama. Jakarta : PT.elek Media Komputindo.

Surakhmman, Winarno. 1980. Pengantar Interaksi Mengajar-BelajarDasadasar dan Teknik Metodelogi Pengajaran. Bandung : Tarsito.

Sugiyono. 2009. Metode Penelitian Kuantitatif, Kualitatif Dan R\&D. Bandung: Alfabeta.

Sukardi. 2008. Metodologi Penelitian Pendidikan. Jakarta: Bumi Aksara.

Sumarwan, Ujang. 2011. Perilaku Konsumen: Teori Dan Penerapannya Dalam Pemasaran. Bogor: Ghalia Indo.

Suryabrata, Sumadi. 2011. Psikologi Pendidikan. Jakrta : Grafindo Persada.

Suryana, 2008. Kewirausahaan Pedoman Praktis: Kiat Dan Proses Menuju Sukses, Jakarta: Salemba Empat.

Supatra. Agnes Andriani. 2009. Intensi Berwirausaha Pada Mahasiswa Ditinjau Dari Self Efficacy. 
Pengaruh Perilaku Pengambilan Resiko dan Kelompok Referensi Terhadap Niat Berwirausaha Mahasiswa Pendidikan Ekonomi STKIP Nurul Huda Kabupaten OKU Timur

Supranto, J Dan Limakrisna, Nandan H, (2007)Perilaku Konsumen Dan Strategi Pemasaran Untuk Memenangkan Persaingan Bisnis, Edisi Pertama Jilid 1, Mitra Wacana Media, Jakarta.

Susanto, A.B.(2009). Leadpreneurship: Pendekatan Strategic Management Dalam Kewirausahaan. Jakarta: Erlangga.

Sutrisno, Hadi. (2002). Metodologi Research 2. Yogyakarta : Andi Offset.

Tampubolon, Manahan. 2004. "Prinsip-prinsip Kewirausahaan”. Jakarta : Ghalia Indonesia.

Tarikotillah, Astik.(2017). Pengaruh Pengetahuan, Kelompok Acuan, Motivasi, Dan Lokasi Bank Terhadap Keputusan Masyarakat Muslim Melakukan Pembiayaan Di Bank Syariah(Studi Kasus Pada Masyarakat Muslim Di Kota Surakarta ). IAIN Surakarta.

Tarmuji, Tarsis. 2006. "Prinsip-prinsip Kewirausahaan”. Yogyakarta : Liberty.

Tudor, Keith R. \& Carley, Susan S. (1998). Reference Group Theory Revisited. Journal International (on-LINE). http://www.sbaer.uca.edu/res5/6/2004 diakses pada 4 Februari 2015.

Van Praag., C. Mirjam., dan Peter H Versloot. 2007. A Review of Recent Research: What Is the Value of Entrepreneurship?. Disampaikan pada IZA Discussion Paper, University of Amsterdam and Tinbergen Institute, Netherlands, Agustus 2007.

Vemmy, S.C. 2012. Faktor-Faktor Yang Mempengaruhi Intensi Berwirausaha Siswa Smk. Jurnal Pendidikan Vokasi, 2 (1): 117-126.

Widjaja Amin Tunggal, 2008. “Audit Manajemen”. Jakarta : Rieneka Cipta.

Wijaya, Tony. Dkk (2015). Intensi Berwirausaha Mahasiswa: Perspektif Pengambilan Risiko. Universitas Negreri Yogyakarta: Jurnal Siasat Bisnis Vol. 19 No. 2, Juli 2015 109-123.

Winkel,W.S. 2009. “Psikologi Pengajaran”. Yogyakarta : Media Abadi.

Zimmer, W.T. 2008. "Essential Of Entrepreneurship and Small Business Management". Third Edition. New York : Prentice-Hall. 
Siti Afifah

Http://Ekonomi.Kompas.Com/Agustus2017.Badan Pusat Statistik. (Diakses Pada 28 Februari 2108).

http://www.pendidikanekonomi.com/2014/07/intensi-niat-berwirausaha.html 